\title{
Persistent albedo reduction on southern Icelandic glaciers due to ashfall from the 2010 Eyjafjallajökull eruption
}

\author{
Rebecca Möller ${ }^{\mathrm{a}, \mathrm{b}, *}$, Pavla Dagsson-Waldhauserova ${ }^{\mathrm{c}, \mathrm{d}}$, Marco Möller ${ }^{\mathrm{e}, \mathrm{f}}$, Peter A. Kukla ${ }^{\mathrm{b}}$, \\ Christoph Schneider, Magnús T. Gudmundsson ${ }^{\mathrm{g}}$ \\ ${ }^{a}$ Department of Geography, RWTH Aachen University, Wüllnerstrasse 5b, 52062 Aachen, Germany \\ ${ }^{\mathrm{b}}$ Geological Institute, Energy and Minerals Research Group, RWTH Aachen University, Wüllnerstrasse 2, 52062 Aachen, Germany \\ ${ }^{\mathrm{c}}$ Faculty of Environmental Sciences, Agricultural University of Iceland, Keldnaholt, Reykjavik 112, Iceland \\ ${ }^{\mathrm{d}}$ Faculty of Environmental Sciences, Czech University of Life Sciences, Prague 165 21, Czech Republic \\ ${ }^{\mathrm{e}}$ Institute of Geography, University of Bremen, Bibliothekstrasse 1, 28359 Bremen, Germany \\ ${ }^{\mathrm{f}}$ Geography Department, Humboldt Universität zu Berlin, Unter den Linden 6, 10099 Berlin, Germany \\ ${ }^{\mathrm{g}}$ Nordvulk, Institute of Earth Sciences, University of Iceland, Sturlugata 7, 101 Reykjavik, Iceland
}

\section{A R T I C L E I N F O}

Edited by Menghua Wang

Keywords:

Volcanic eruption

Ash dispersal

Glacier albedo

MODIS

Modeling

Eyjafjallajökull

Iceland

\begin{abstract}
A B S T R A C T
In April and May 2010 the Icelandic volcano Eyjafjallajökull experienced an explosive eruption that led to substantial ashfall across the central-southern parts of the island. The resulting ash deposits covered Eyjafjallajökull, Mýrdalsjökull and parts of Vatnajökull ice caps. In order to quantify the influence of these deposits on albedo, we analyzed albedo evolution across Eyjafjallajökull and Mýrdalsjökull ice caps over the period 2001-2016 using the MOD10A1 and MCD43A3 data products of the Moderate Resolution Imaging Spectroradiometer (MODIS) sensor onboard the Terra and Aqua satellites. A geostatistical model with a daily temporal resolution was used to delineate areas on the ice caps that show distinct ash cover-related albedo reductions over the post-eruption period. Results suggest that despite an overall decrease of the ash cover-related albedo reductions with time, noticeable albedo reductions persist on both, Eyjafjallajökull and Mýrdalsjökull over the entire post-eruption period. These reductions show means of $0.19 \pm 0.11$ and $0.17 \pm 0.10$, respectively, and occur most prominently during the summer seasons. Persistent albedo reductions are in agreement with and limited to areas of higher ash deposition during the volcanic eruption such as the southern parts of Eyjafjallajökull and Mýrdalsjökull ice caps. In addition, redistribution of Eyjafjallajökull ash deposited on the lowlands in southern Iceland contributed to dust storm events in the years after the eruption and caused additional albedo reductions.
\end{abstract}

\section{Introduction}

On 14 April 2010 a massive subglacial, explosive eruption began at the summit caldera of Eyjafjallajökull volcano, southern Iceland (Gudmundsson et al., 2011). The explosive part of the eruption lasted until 22 May 2010 and produced about $0.27 \mathrm{~km}^{3}$ of mostly fine-grained, airborne tephra which generated ash fallout over central southern Iceland and even over the European continent (Gudmundsson et al., 2012; Stevenson et al., 2012). This fallout of trachyandesitic ash (Borisova et al., 2012) covered not only the ice cap on Eyjafjallajökull volcano itself but also the entire neighboring Mýrdalsjökull ice cap and the southwestern parts of Vatnajökull ice cap (Fig. 1; Gudmundsson et al., 2012). Eyjafjallajökull and the southern part of Mýrdalsjökull received ash deposits of at least several centimeters while the northern part of Mýrdalsjökull was covered with $<1 \mathrm{~cm}$ of ash (Gudmundsson et al., 2012). Ash deposition on Vatnajökull ice cap was $<1 \mathrm{~mm}$.

Across off-glacier sites, considerable wind erosion of the freshly deposited ash occurred during storm events over the year following the eruption. This resulted in a partial redistribution of the post-eruption deposition pattern (Arnalds et al., 2013). Hereafter, eroded ash from the proglacial plains around the large ice caps might have also formed deposits across marginal regions of the adjacent glaciers. Eyjafjallajökull and Mýrdalsjökull are also surrounded by active dust hot spots (proglacial plains) with frequent dust storms, i.e. Mýrdalssandur in the east, Landeyjasandur in the west-southwest and Mælifellssandur in the north (Arnalds et al., 2016). Butwin et al. (2018) showed that the deposits from some explosive volcanic eruptions (Volcano Explosive Index $\mathrm{VEI} \geq 3$ ) in Iceland increased the dust/ash storm events for several

\footnotetext{
* Corresponding author.

E-mail address: rebecca.moeller@geo.rwth-aachen.de (R. Möller).
} 

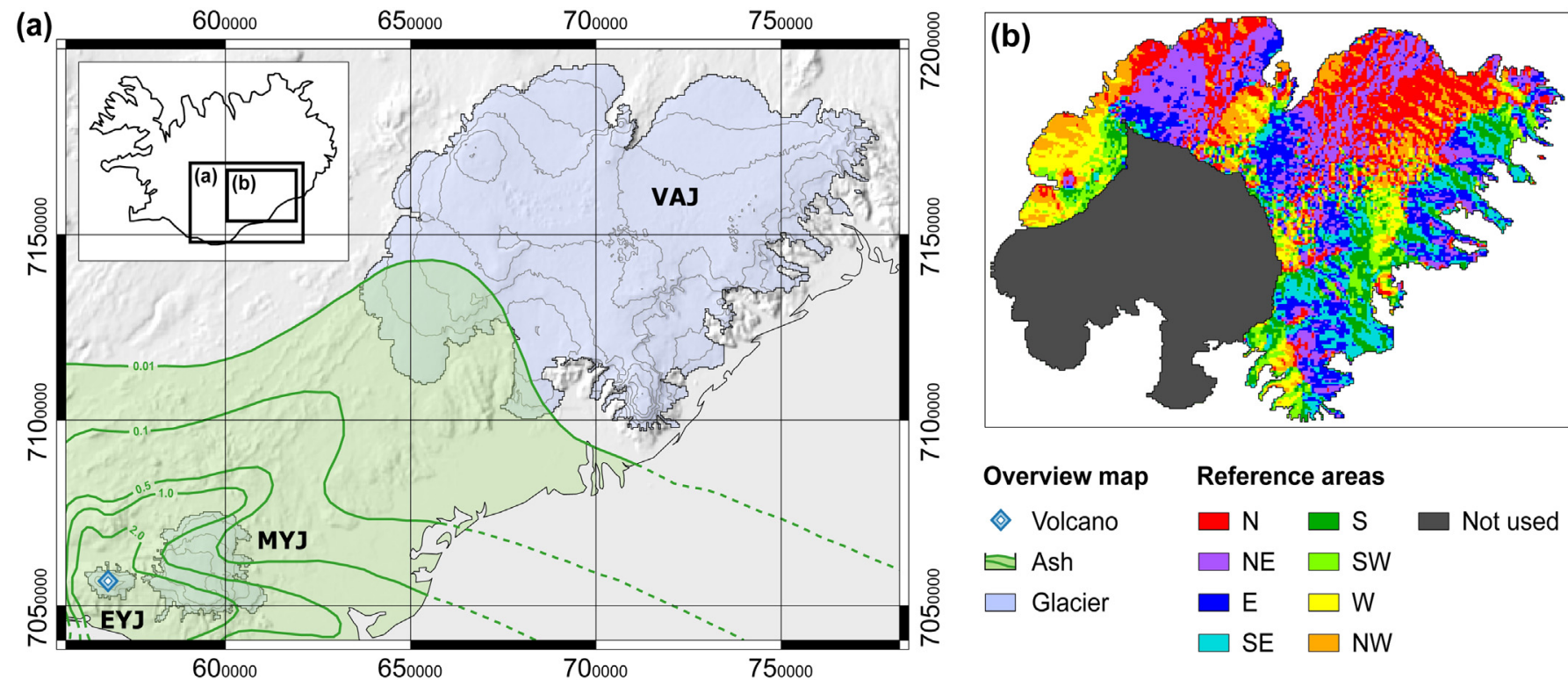

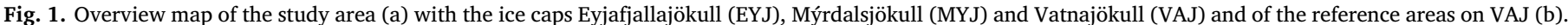

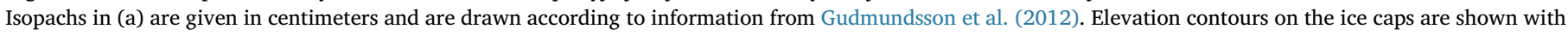

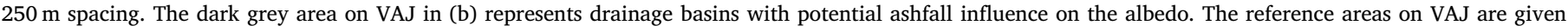
according to terrain aspect (color code).

months after the end of the eruption. This does not count, however, for the eruptions that occurred in winter months.

Across the ablation areas of the glaciers, parts of the ash layers were supposed to be washed away by melt-water flow over the summer season as described by Adhikary et al. (2000). What remained of the ash layers got buried by seasonal snow with the beginning of the winter season. While remaining ash got uncovered again during the following summer throughout the low-lying ablation areas, the ash deposits were supposed to submerge into the ice bodies due to persistent net mass gain and glacier dynamics throughout the accumulation areas. However, with their downward transport by glacier flow, a re-emergence throughout the ablation areas may occur in the future. The emergence of such palaeotephra layers has been documented on Vatnajökull (Larsen et al., 1998).

In cases where ash layers occur at the glacier surface they have a substantial influence on the surface structure (Nield et al., 2013). These are linked to alterations of local energy and mass balance (Dragosics et al., 2016; Möller et al., 2018). Thin deposits, with thicknesses smaller than the surface roughness length of the glacier, primarily enhance ablation as a response of lowering of surface albedo (Möller et al., 2016). Small-scale changes of the glacier-surface structure in turn influence surface albedo. Hence, albedo reductions are the major consequence of supraglacial ash or dust deposits on glaciers in any case. Multi-annual persistence of albedo reduction due to ashfall has been documented for northern Vatnajökull by analyzing fallout from the 2004 explosive, subglacial eruption of Grímsvötn volcano (Möller et al., 2014). In addition, dust deposition from the local dust hot spots occasionally affects the albedo of Vatnajökull, leading to increased snow melt of up to $\sim 0.6 \mathrm{~m}$ in the affected areas (Wittmann et al., 2017). For 2012, Wittmann et al. (2017) report that up to $42 \%$ of ablation in these areas is directly due to volcanic dust deposition.

Glacier surface albedo can be observed by satellite remote sensing (e.g. Racoviteanu et al., 2008). From the Moderate Resolution Imaging Spectroradiometer (MODIS) onboard the Terra and Aqua satellites, ready to use albedo products are available (cf. Section 3 below). The data provide albedo information with a $500 \mathrm{~m}$ spatial resolution and up to daily temporal resolution. The products show the current state of albedo across a glacier surface, including any influence of supraglacial ash deposition. In order to unveil whether certain areas on a glacier are affected by ash deposition and in order to quantify how large the resulting albedo deviations are, compared to hypothetical unaffected conditions, Möller et al. (2014) presented a remote sensing-based modeling method which is capable of quantifying ash-related albedo reductions over glacier surfaces.

Here, we extend this method in several ways (cf. Section 4) in order to account for temporally disturbing influences of a second volcanic eruption (Grímsvötn in 2011) and to cope with diverse and widespread deposition areas. The extended method is then applied to analyze the influence of deposited ash on the surface albedo of Eyjafjallajökull and Mýrdalsjökull ice caps (Fig. 1) over the period 2010-2016, following the April-May 2010 eruption of Eyjafjallajökull volcano. We present spatial patterns of surface albedo changes across the ice caps and discuss to which extent these patterns can be related to either the original post-eruption ash deposition pattern or to other processes such as subsequent resuspension of volcanic ashes in dust storm events.

\section{Study area}

Eyjafjallajökull volcano lies within the eastern volcanic zone of Iceland which has developed as a propagating rift (Thordarson and Larsen, 2007). The volcano is characterized by a transitional alkaline magmatism which can erupt both basaltic and andesitic materials (Jakobsson et al., 2008).

Eyjafjallajökull is located close to the southern coast of Iceland (Fig. 1) and is covered by an identically named ice cap of $\sim 80 \mathrm{~km}^{2}$ which reaches up to $1635 \mathrm{~m}$ a.s.l. (Björnsson and Pálsson, 2008). The neighboring Mýrdalsjökull ice cap ( $\sim 1510 \mathrm{~m}$ a.s.l.) covers the volcano Katla and extends over $\sim 590 \mathrm{~km}^{2}$, making it the fourth largest glacier in Iceland (Björnsson and Pálsson, 2008). Vatnajökull ice cap is the largest glacier of the island $\left(\sim 7800 \mathrm{~km}^{2}\right)$. It covers different volcanoes and reaches up to $2110 \mathrm{~m}$ a.s.l. (Björnsson, 2017).

The locations of the three ice caps spatially coincide with the locations of highest precipitation in Iceland which are due to orographic effects in conjunction with the prevailing wind direction Southeast (Crochet et al., 2007). In recent years, the ice caps have experienced continuously negative, annual glacier-wide mass balances (Björnsson et al., 2013). 


\section{Data}

Albedo data are derived from two data products of the MODIS sensors onboard the Terra and Aqua satellites. These are the snow product MOD10A1 version 6 and the land-albedo product MCD43A3 version 6 (Hall et al., 2002; Schaaf et al., 2002; Toller et al., 2013). The former provides blue-sky albedo across snow or ice-covered areas on a daily basis and is based on Terra MODIS data only. The latter provides black-sky and white-sky albedo of snow-free land areas with a resolution of daily 16-day averages and is generated from both, Terra and Aqua MODIS data. Both products have a spatial resolution of $500 \mathrm{~m}$. They were obtained from the NASA Earthdata Search engine (https:// search.earthdata.nasa.gov/search).

We use both types of albedo data as emerging palaeotephra layers across parts of the ablation areas of Mýrdalsjökull and Vatnajökull lead to substantial darkening of bare ice areas (Larsen et al., 1998). This darkening is strong enough to prevent the respective areas from being identifiable as ice-covered areas in the automated generation of the MOD10A1 product. However, these areas are covered in the MCD43A3 product for the same reason. We use this coincidence to create neargapless albedo fields by replacing the on-glacier albedo data voids in the MOD10A1 product by blue-sky albedo data calculated from MCD43A3 data. Due to the differing temporal resolution of both products, we create the combined albedo fields at the same resolution as the MCD43A3 data, i.e. daily moving 16-day averages. We calculate MCD43A3 blue-sky albedo by averaging between black-sky and whitesky albedo data. This is considered reasonable as the two can be assumed to be comparable at the latitude of the study area (Stroeve et al., 2005). The same procedure for establishment of gapless albedo fields has already been successfully applied for albedo fields of Vatnajökull by Möller et al. (2014). Also, the credibility of the MODIS albedo data with respect to in-situ measurements has been documented via a multi-year comparison to automatic weather station data by Möller et al. (2014).

The 16 day-averaged albedo fields with a daily temporal resolution for Eyjafjallajökull and Mýrdalsjökull (Fig. 1) are generated over the time period 2001-2016. For each year, the data cover the period 17 January to 2 December. For the missing days, no MODIS albedo data are available due to absence of daylight. Despite using a combination of MOD10A1 and MCD43A3 data, some data voids cannot be filled in the final 16-day albedo fields. This is either due to persistent cloud coverage or due to non-classifiable glacier-surface characteristics. On average, $83.0 \%$ of the grid cells of the combined 16-day albedo fields are taken from MOD10A1 data, while only $0.7 \%$ are taken from MCD43A3 data. However, maximum portions of MCD43A3 are as high as $8.5 \%$. Data voids are present in $16.3 \%$ of the grid cells.

Glacier outlines of Eyjafjallajökull, Mýrdalsjökull and Vatnajökull ice caps as well as drainage basin delineations within Vatnajökull are taken from the Randolph Glacier Inventory (Pfeer et al., 2014). Digital elevation model data of Vatnajökull are taken from the $30 \mathrm{~m}$ resolution Advanced Spaceborne Thermal Emission and Reflection Radiometer (ASTER) Global Digital Elevation Model (GDEM) version 2 (Tachikawa et al., 2011).

A common spatial domain is established for all data types. This domain shows a regular $500 \mathrm{~m}$ resolution grid using Universal Transverse Mercator (UTM) zone 27 N. For the ASTER GDEM data the co-registration is combined with a simultaneous bilinear resampling from 30 to $500 \mathrm{~m}$ spatial resolution.

\section{Methods}

For each day after the end of the eruption of Eyjafjallajökull on 22 May 2010 (from 30 May 2010 to 2 December 2016), we determine those areas on Eyjafjallajökull and Mýrdalsjökull ice caps with a significant reduction of glacier-surface albedo due to ash deposition. This uses a two-step approach, which compares directly MODIS observed albedo fields with hypothetic albedo fields, which would have shown up without the influence of the volcanic ashfall. In step one, the hypothetic albedo fields are generated. In step two, a threshold criterion and a test for statistical significance are used to identify areas with significant ash influence on albedo. The threshold criterion is calibrated using a cross-validation procedure. The methodology largely follows the one developed by Möller et al. (2014).

As preparatory work for step one, a two-sided lookup table is generated that contains the combined MODIS albedo fields of Eyjafjallajökull and Mýrdalsjökull ice caps of all days $n$ of the preeruption period (from 17 January 2001 to 6 April 2010) as predict and $\left(\alpha_{\text {pre, } n}\right)$ and spatially averaged albedo values of eight predefined reference areas $X$ on Vatnajökull ice cap of the same days $n$ as predictor $\left(\overline{\beta_{p r e, X, n}}\right)$. The reference areas $X$ are delimited according to terrain aspect classified into $45^{\circ}$ sectors, i.e. $X \in[N, N E, E, S E, S, S W, W, N W]$ (Fig. 1). Parts of the southwestern drainage basin of Vatnajökull that were also affected by ashfall from the Eyjafjallajökull 2010 eruption (Gudmundsson et al., 2012) and that, in addition, received considerable ash deposition from an eruption of Grímsvötn volcano in 2011 are left out during the delineation. The completed lookup table serves as a basis for generation of the hypothetic albedo fields in step one.

The application of a lookup table-based method implicitly assumes that the albedo fields across the three ice caps have coherent seasonal cycles over the course of the year. This is a reasonable assumption as they all experience a similar climate (cf. Section 2). It is furthermore supported by the fact that the standardized trajectories of ice cap-wide mean albedos over the pre-eruption period show median absolute differences of less than one quarter of a standard deviation when comparing Eyjafjalljökull and Mýrdalsjökull to the reference areas on Vatnajökull.

In step one, we estimate the hypothetic albedo fields of Eyjafjallajökull and Mýrdalsjökull ice caps for all days $m$ of the posteruption period (from 30 May 2010 to 2 December 2016). This is done on the basis of spatially averaged albedo values of the reference areas $X$ of the respective days $\left(\overline{\beta_{p o s t, X, m}}\right)$ and by using the entries in the lookup table. For each of the $\overline{\beta_{p o s t, X, m}}$ one hypothetic albedo field $\left(\hat{\gamma}_{X, m}\right)$ is generated. Each $\hat{\gamma}_{X, m}$ is generated by averaging all $\alpha_{p r e, n}$ from the lookup table whose associated $\overline{\beta_{\text {pre }, X, n}}$ lie within a \pm 0.02 range around the respective $\overline{\beta_{p o s t, X, m}}$. The $\widehat{\gamma}_{X, m}$ are averaged to form a mean hypothetic albedo field $\gamma_{m}$. Deviating from Möller et al. (2014), we hereby exclude reference areas that show temporary albedo disturbances due to marginal ash deposition from the eruptions of Eyjafjallajökull in 2010 (Gudmundsson et al., 2012) and Grímsvötn in 2011 (Tesche et al., 2012) or secondary sand and ash depositions from dust storm events (e.g. Wittmann et al., 2017). The exclusion procedure is based on a test for self-consistency of the eight different $\overline{\beta_{\text {post }, X, m}}$ of the respective days. To prepare for the test, validity spaces of the relationships between area-averaged albedos of adjacent reference areas were derived over the pre-eruption period (Fig. 2a). The validity spaces are spanned by all pairs of the respective $\overline{\beta_{p r e, X, n}}$ that occur in the pre-eruption period. They represent the entirety of possible relationships under the assumption of undisturbed albedo conditions. The self-consistency test compares the relationships between the area-averaged albedos of adjacent reference areas of the post-eruption period $\left(\overline{\beta_{\text {post }, X, m}}\right)$ to these validity spaces (Fig. 2a). Hereby, each $\overline{\beta_{p o s t, X, m}}$ is considered in two relationships (e.g. $\overline{\beta_{p o s t, N E, m}}$ vs. $\overline{\beta_{p o s t, N, m}}$ and $\overline{\beta_{p o s t, N E, m}}$ vs. $\overline{\beta_{p o s t, E, m}}$ ). Any of the post-eruption albedo relationships that lie outside of their associated validity spaces are treated as invalid. Invalidity means that as at least one of the reference areas involved shows disturbed albedo conditions at the respective day. We consequently exclude those $\overline{\beta_{\text {post }, X, m}}$ of the respective days that are part of at least one invalid albedo relationship. Fig. 2b gives an overview of the temporarily varying exclusion of certain reference areas over the post-eruption period.

The crucial assumption of undisturbed albedo conditions during the pre-eruption period, which is implicitly made here, is regarded as reasonable despite an eruption of Grímsvötn volcano in the center of 
(a)
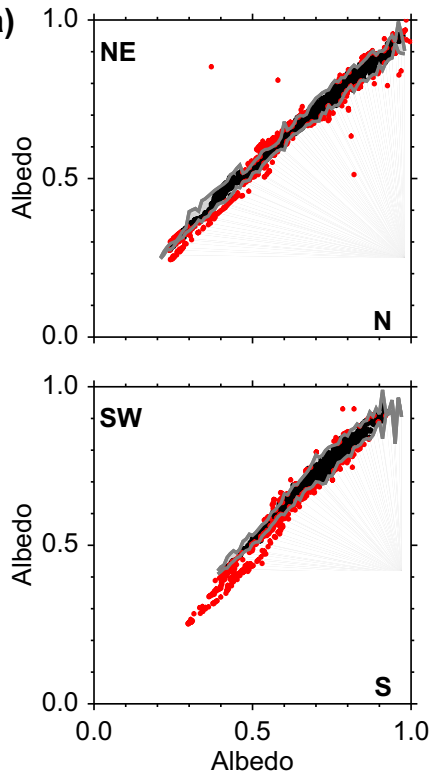
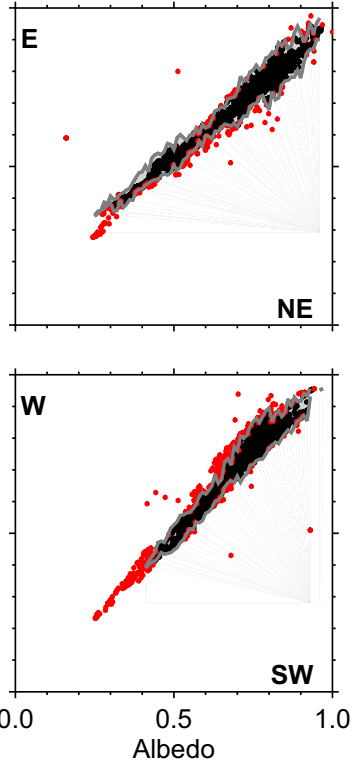
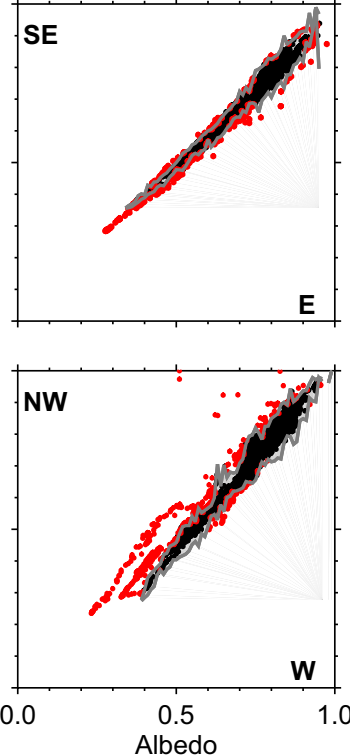

Albedo

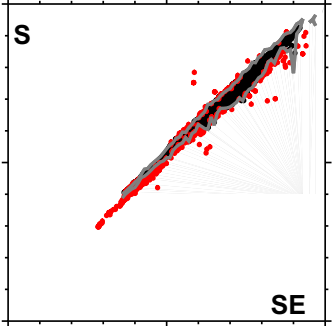

SE

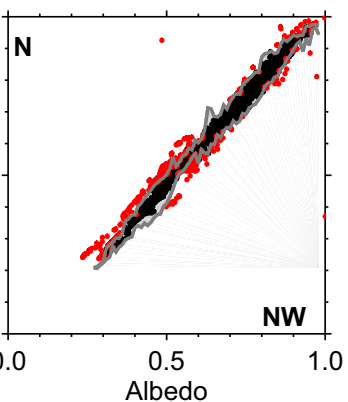

2000

Pre-eruption:

Validity spaces

Post-eruption:

Valid relationships

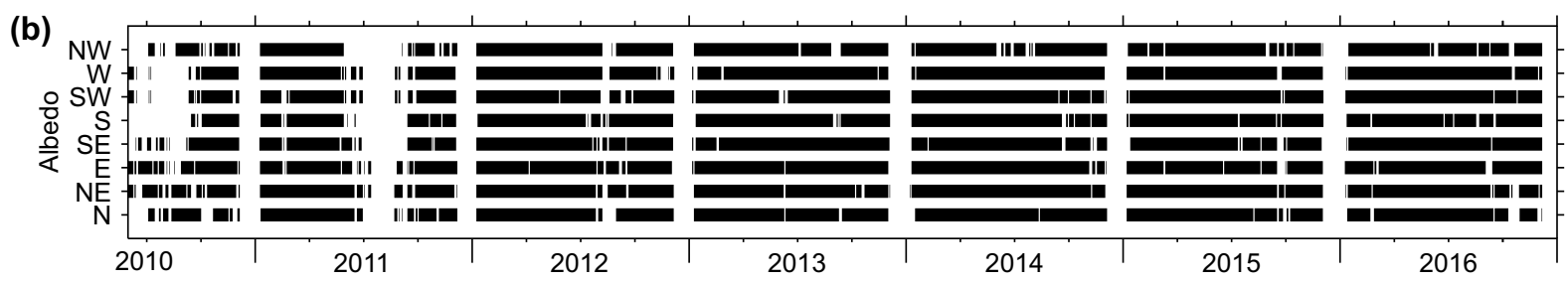

(c)

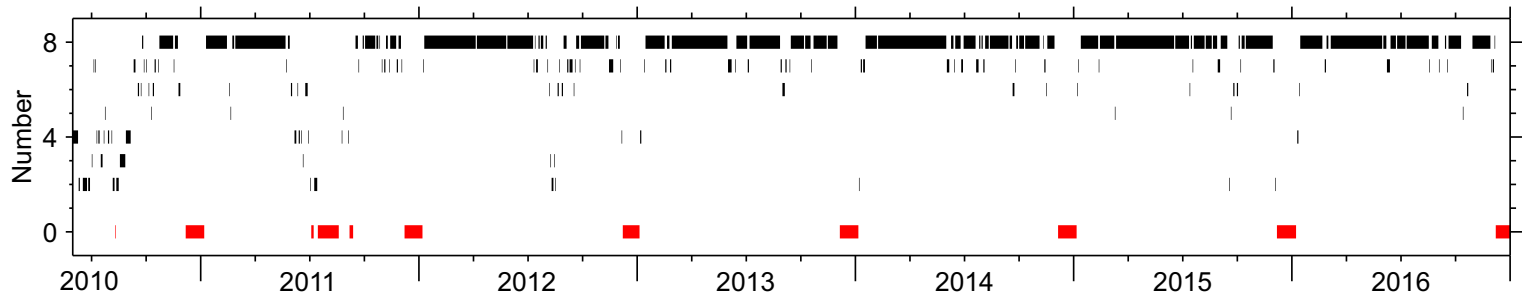

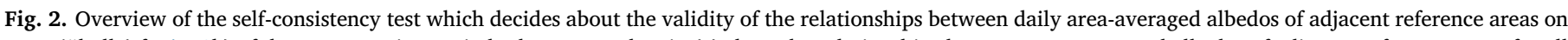

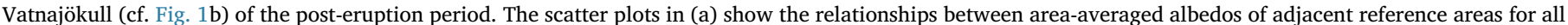

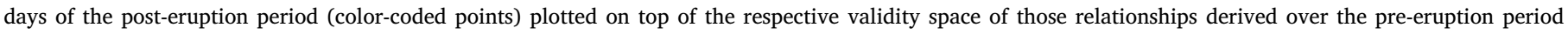

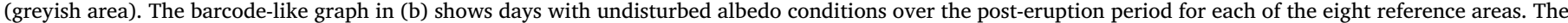

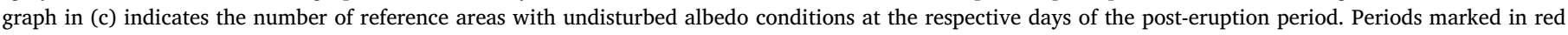

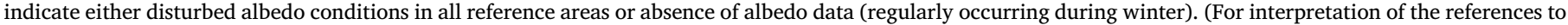
color in this figure legend, the reader is referred to the web version of this article.)

Vatnajökull in November 2004. Findings of Möller et al. (2014) show that ash-related albedo reductions associated with this event were only present across very small areas: Right after the eruption, $425 \mathrm{~km}^{2}$ across northern Vatnajökull were affected, but fresh winter snow buried the deposited ashes within two weeks; over the four years following, ashrelated albedo reductions were only found to be present across a remainder of $24 \mathrm{~km}^{2}$ on average, leaving $99.7 \%$ of Vatnajökull under undisturbed albedo conditions.

As preparatory work for step two, we assess the accuracy of the hypothetic albedo fields of Eyjafjallajökull and Mýrdalsjökull by applying a $k$-folds cross validation procedure (Kohavi, 1995; Möller, 2012 ) in order to derive the threshold criterion used in step two. In the cross validation procedure, the folds are formed by $k=9$ subsets of the lookup table. We create each subset of the lookup table on the basis of albedo data from eight years within the nine-years pre-eruption period.
For each day $i$ of the remaining year, we generate the eight hypothetic albedo fields $\hat{\gamma}_{X, i}$ as described above, but only using the entries in the eight-year subset of the lookup table as a basis. We then compare the hypothetic albedo fields $\left(\hat{\gamma}_{X, i}\right)$ to the combined MODIS albedo field of the respective day $\left(\alpha_{p r e, i}\right)$. As no ash influence on albedo is assumed for the pre-eruption period, these albedo fields should ideally equal each other. We calculate the root mean square (RMS) errors between $\alpha_{p r e, i}$ and each of the eight $\widehat{\gamma}_{X, i}$. Unlike Möller et al. (2014), we calculate the RMS errors as functions of terrain elevation using moving $50 \mathrm{~m}$ intervals and we calculate it separately for each of the two ice caps (Fig. 3). For each ice cap, this procedure is repeated nine times, yielding a set of nine RMS error functions for each day of a year. The means of these nine RMS error functions are used as daily-varying threshold criteria in step two.

In step two, we identify areas on Eyjafjallajökull and Mýrdalsjökull 

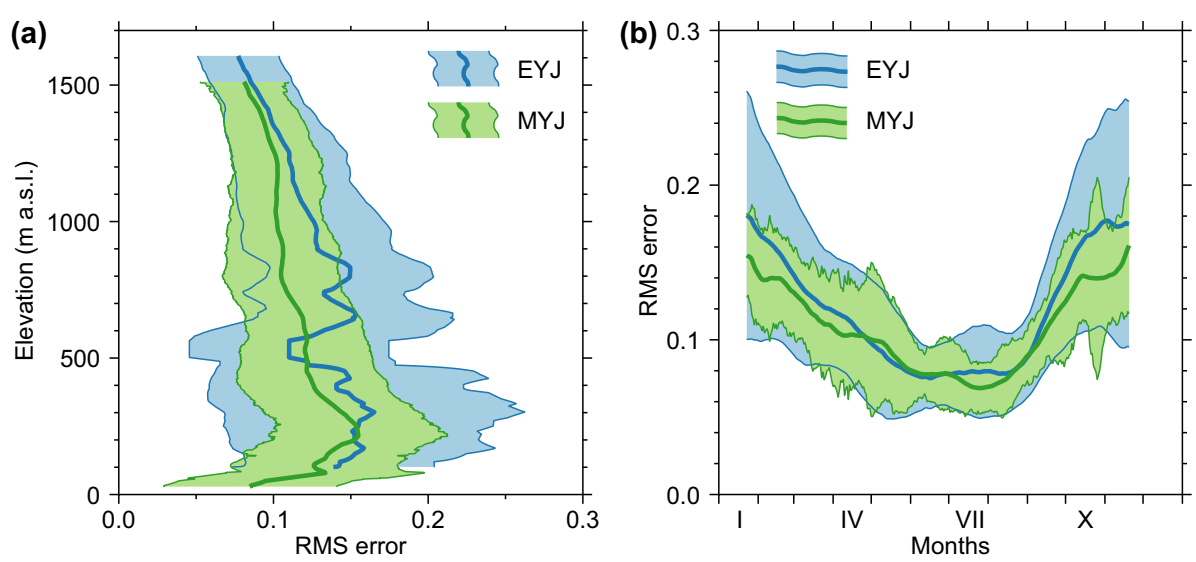

Fig. 3. Mean courses of root mean square (RMS) errors between the combined MODIS albedo fields of Eyjafjallajökull and Mýrdalsjökull and the respective modeled albedo fields over terrain elevation (a) and over time (b). RMS errors are derived by cross validation over the period 2001-2009 (cf. Section 3). The ranges in (a) represent variability of the RMS errors over time and the ranges in (b) variability over terrain elevation.

ice caps for all days $m$ of the post-eruption period (from 30 May 2010 to 2 December 2016) for which a significant reduction of albedo due to an ashfall influence can be expected. Therefore, we consecutively compare the combined MODIS albedo field $\alpha_{\text {post, } m}$ to each of the hypothetic albedo fields $\left(\hat{\gamma}_{X, m}\right)$ of the same day. Areas that consistently show a negative albedo deviation exceeding the threshold criterion of the respective day and terrain elevation in all comparisons are marked as potentially ash influenced. We thus interpret the threshold criteria (mean RMS errors of the pre-eruption period) as a measure for natural albedo variability within the respective day and elevation. Albedo deviations exceeding this threshold are assumed to be attributable to an external forcing like the Eyjafjallajökull 2010 ash deposition. A Student's $t$-test is finally applied to delineate those parts of the potentially ash influenced areas in which the negative deviation between combined MODIS albedo field $\alpha_{\text {post, } m}$ and mean hypothetic albedo field $\gamma_{m}$ is statistically significant at a level of at least $95 \%$. These areas are termed 'significantly ash influenced' and form the final result of the workflow.

More detailed descriptions of the applied methodology and more in depth discussions about the related theoretical background are provided in Möller et al. (2014).

\section{Results}

Glacier surface albedo develops along a characteristic inter-annual course over the pre-eruption period 2001-2009 (Fig. 4). Highest values occur towards the end of the accumulation season in late winter. They are followed by continuous decrease towards the lowest values, which most regularly occur in early August after peaking of the ablation season. The increase back to high albedo values during winter time is distinctly faster than the previous decrease. While the former usually only takes about three months, the latter extends over five months.

This inter-annual albedo evolution, however, varies distinctly between Eyjafjallajökull, Mýrdalsjökull and the reference areas on Vatnajökull (Fig. 4). Over most of the year, Mýrdalsjökull shows the lowest area-averaged albedo, ranging between $0.79 \pm 0.07$ in early March and $0.28 \pm 0.05$ in mid-August. Vatnajökull, in general, shows the highest area-averaged albedo with up to $0.80 \pm 0.05$ in late winter and just down to $0.46 \pm 0.05$ in summer. On Eyjafjallajökull, areaaveraged albedo increases to similarly high values as on Vatnajökull during winter $(0.80 \pm 0.05)$, but over the summer season it decreases to values almost as low as those on Mýrdalsjökull (0.32 \pm 0.04$)$.

On all three ice caps also the years 2013-2016 largely follow this characteristic intra-annual course (Fig. 4). Marked deviations occur during 2010-2012, with 2010 being by far the most pronounced. In this year, area-averaged albedo on Eyjafjallajökull drops from 0.68 before the start of the April/May volcanic eruption to 0.11 right after its end. With few exceptions, it stays on a low level until the end of the summer period. Considerable drops of area-averaged albedo are also evident on
Mýrdalsjökull and Vatnajökull. However, for the latter the drop is far smaller than on Eyjafjallajökull and Mýrdalsjökull. Also during 2011 and 2012 the intra-annual albedo evolutions on Eyjafjallajökull and Mýrdalsjökull show considerably stronger albedo decreases over the summer seasons than in the pre-eruption period. This is especially pronounced during July 2011. Stronger than usual albedo decreases are visible during the mid-summer season of 2011 also on Vatnajökull. This feature persists in 2012, but in a less pronounced form. A marked contrast to Eyjafjallajökull and Mýrdalsjökull is the observation that the summer decrease of area-averaged albedo on Vatnajökull tends to be less intensive during the 2014-2016 period than during the pre-eruption period 2001-2009.

Substantial parts of the decreases of area-averaged albedo across Eyjafjallajökull and Mýrdalsjökull are attributable to the 2010 volcanic eruption. On average, we identified a significant ash influence on the albedo for $15.4 \%$ of the area of Eyjafjallajökull and for $10.9 \%$ of the area of Mýrdalsjökull over the post-eruption period 2010-2016, including all the winter periods (Fig. 5b). Within these areas the albedo was reduced by $0.19 \pm 0.11$ (mean \pm one sigma) and $0.17 \pm 0.10$, respectively (Fig. 5a).

On Eyjafjallajökull, the significantly ash-influenced areas show a clear tendency towards smaller extents over the post-eruption period. In $2010,28.4 \pm 21.8 \%$ of the ice cap's area is identified as significantly ash-influenced, with half of the days showing extents between $18.4 \%$ and $51.6 \%$. This value almost halves to only $15.2 \pm 15.5 \%$ over 2011-2016 (Fig. 5b). The actual albedo reduction within the significantly ash influenced areas tends to be less intensive with increasing temporal distance to the eruption. Albedo reduction decreased by about one fifth from $0.24 \pm 0.11$ in 2010 to $0.20 \pm 0.10$ in 2016 .

The spatial distribution of the significantly ash-influenced areas across the ice cap shows a characteristic pattern (Fig. 6). They concentrate on the southern parts of Eyjafjallajökull over most of the days for which an influence was detected. This pattern persists in the period 2010-2016. During all years of the post-eruption period, the extents of the significantly ash-influenced areas tend to increase towards the end of the summer season (Fig. 7a).

On Mýrdalsjökull a similar trend in the extents of the significantly ash-influenced areas as on Eyjafjallajökull is evident (Fig. 5b). However, the albedo reduction within the significantly ash-influenced areas shows a smaller decrease with increasing temporal distance to the eruption as on Eyjafjallajökull. The albedo reduction decreases by just $14 \%$ from $0.21 \pm 0.10$ in 2010 to $0.18 \pm 0.08$ in 2016 (Fig. 5a). During most of the years of the post-eruption period, the influence concentrates on the southwestern and southern parts of the ice cap (Figs. 6 and 8). The northern parts generally show the shortest ash influences on albedo. This pattern is most pronounced in 2010, 2011 and 2016. In 2012 and 2015, in contrast, the entire central plateau of Mýrdalsjökull shows significant ash influence over up to three months. 

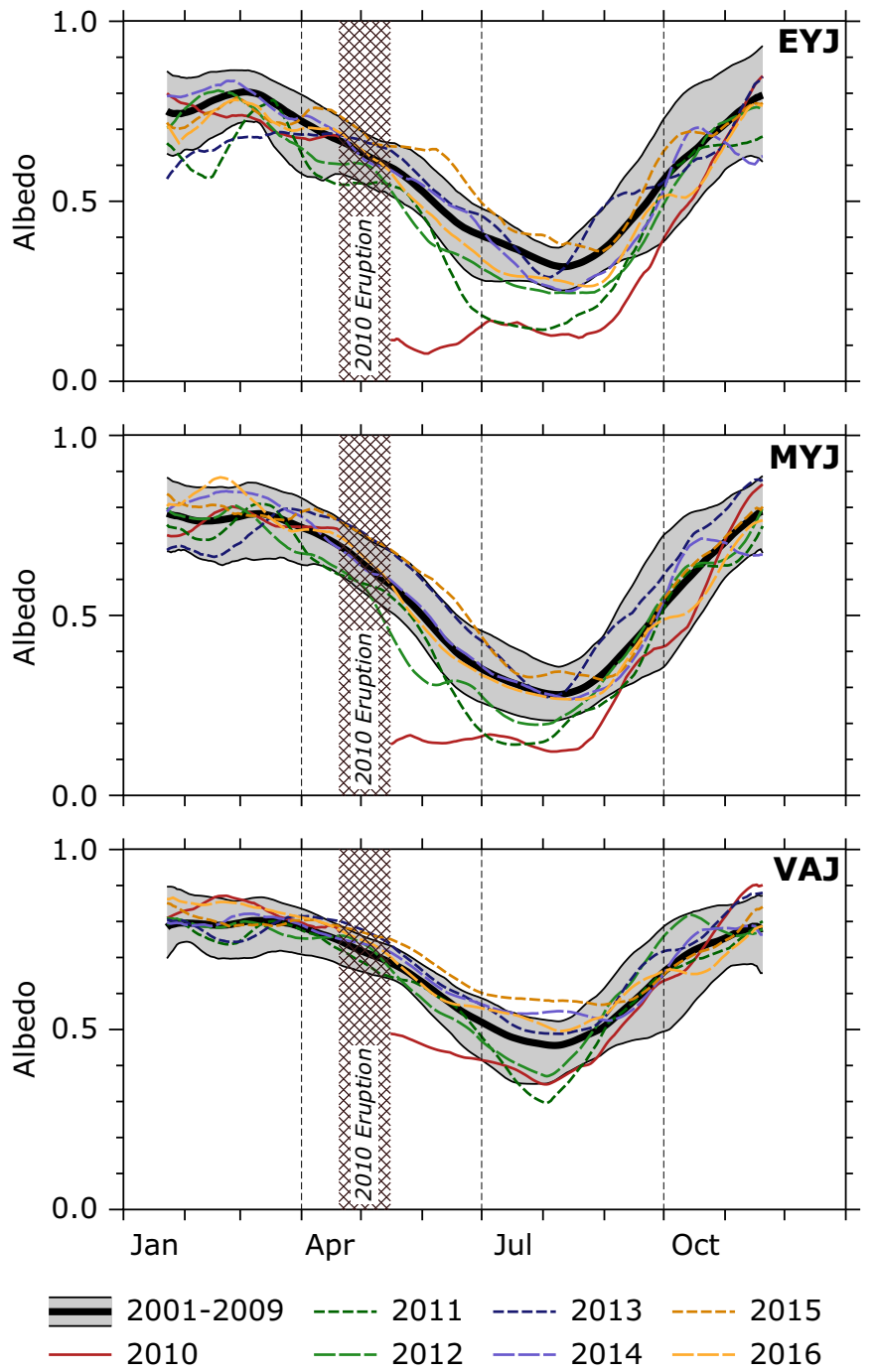

Fig. 4. Annual cycles of albedo across Eyjafjallajökull (EYJ), Mýrdalsjökull (MYJ) and Vatnajökull (VAJ) ice caps over the post-eruption period 2010-2016. Data are based on the combined MODIS albedo fields and are smoothed by a moving monthly average. For VAJ only data from inside the eight reference areas (cf. Fig. 1b) are presented. The mean annual cycles of the period 2001-2009 are displayed along with their one sigma ranges. For 2010 no albedo data are displayed during the eruption period itself.

The general tendency of increasing extents of the significantly ash-influenced areas towards the ends of the summer seasons is also observed for Mýrdalsjökull (Fig. 7).

A particularly large extent of significantly ash-influenced areas on Mýrdalsjökull is evident over up to two months in April-June 2012 (Fig. 6). This long duration of albedo reductions across such vast parts of the central plateau of the ice cap is unprecedented during all other spring seasons of the study period. It coincides with the by far largest extent of significantly ash-influenced areas on a single day on Mýrdalsjökull $\left(529 \mathrm{~km}^{2}\right)$ which was identified for 21 May 2012 (Fig. 7b).

\section{Discussion}

The difference in albedo between Eyjafjallajökull and Vatnajökull is noticeable (Fig. 4) and potentially suggests problems for the applied methodology of assigning hypothetic albedo fields to Eyjafjallajökull and Mýrdalsjökull on the basis of spatially-averaged albedo across Vatnajökull. This difference, however, appears over the entire annual circle and thus cannot be attributed to spatial or temporal climate
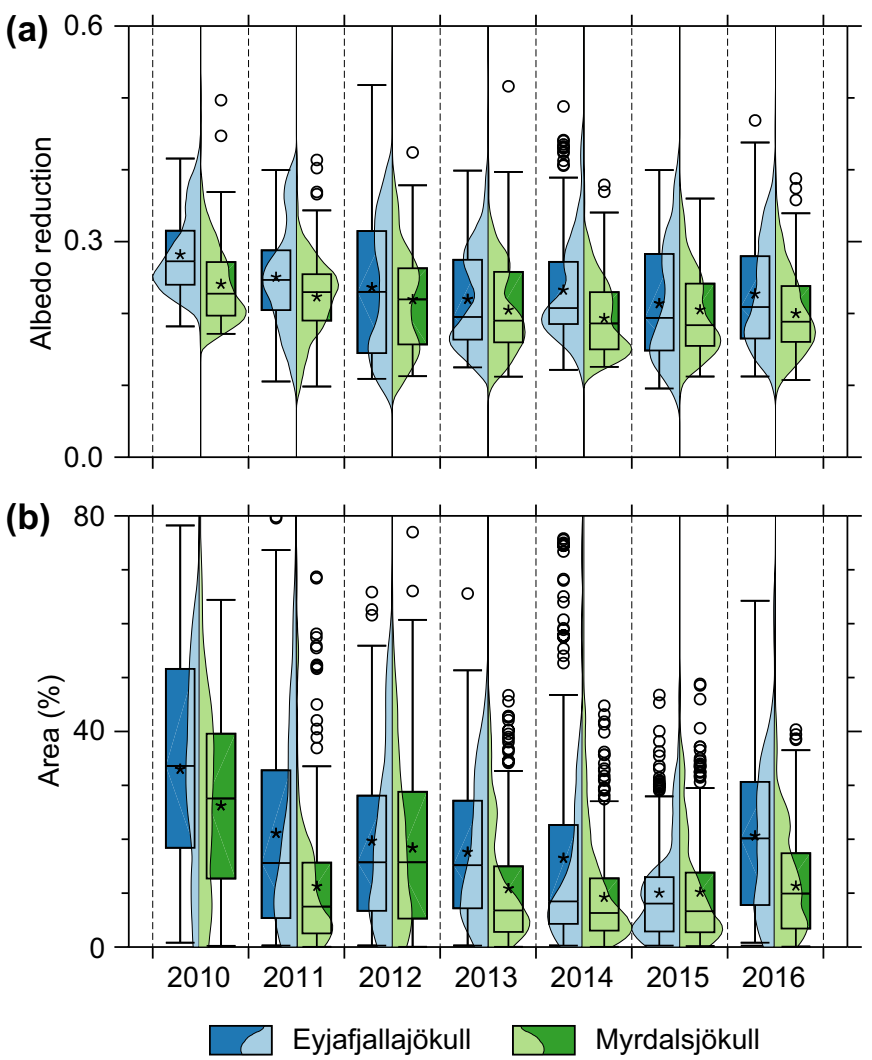

Fig. 5. Evolution of areas with significant, ash-influenced albedo reductions on Eyjafjallajökull and Mýrdalsjökull ice caps over the post-eruption period 2010-2016. Box plots represent daily ice cap-wide data subdivided by years. The mean albedo reduction (a) within the significantly ash-influenced areas is shown along with the extent of these areas (b). The latter is given as proportion of the respective entire ice cap. The color-coded boxes range between upper and lower quartile of the distributions. Medians are indicated by horizontal lines, means by asterisks. Outliers are represented by open circles. The overlying violin plots show the related relative frequency distributions.

variability. It is rather a method-inherent feature. Satellite-based albedo observations are more reliable over continuous glaciers than across their peripheral areas. This is due to stronger influences of crevasserelated surface disturbances across steeper and more segmented terrain and also due to general edge effects (e.g. Möller and Möller, 2017). The latter imply erroneously low albedo values, resulting from a combination of partly glacierized and partly non-glacierized terrain within one pixel. Another possible explanation would be that Eyjafjallajökull and Mýrdalsjökull generally receive more impurities as they are surrounded by three dust hot spots. Both alternatives suggest that the systematic differences between the albedo on the three ice caps are, to a large degree, a characteristic and consistent feature. It does to our understanding therefore not inhibit applying the method we used to derive albedo reductions for the ash-influenced parts of Eyjafjallajökull and Mýrdalsjökull.

The substantial reduction of ice cap-wide albedo on Eyjafjallajökull and Mýrdalsjökull during the eruption period (Fig. 4) provides evidence of the strong initial relation between volcanic ashfall and albedo decrease. Comparable reductions over the summer season 2010 have also been documented and related to the April-May 2010 eruption of Eyjafjallajökull by Gascoin et al. (2017). We conclude that the significantly negative albedo deviations, which are identified over the post-eruption period 2010-2016, are mostly due to ash influence from the Eyjafjallajökull 2010 eruption. This is strongly supported by a spatial coincidence of areas which show the most intensive, i.e. long lasting, albedo reductions and those areas which experienced highest 

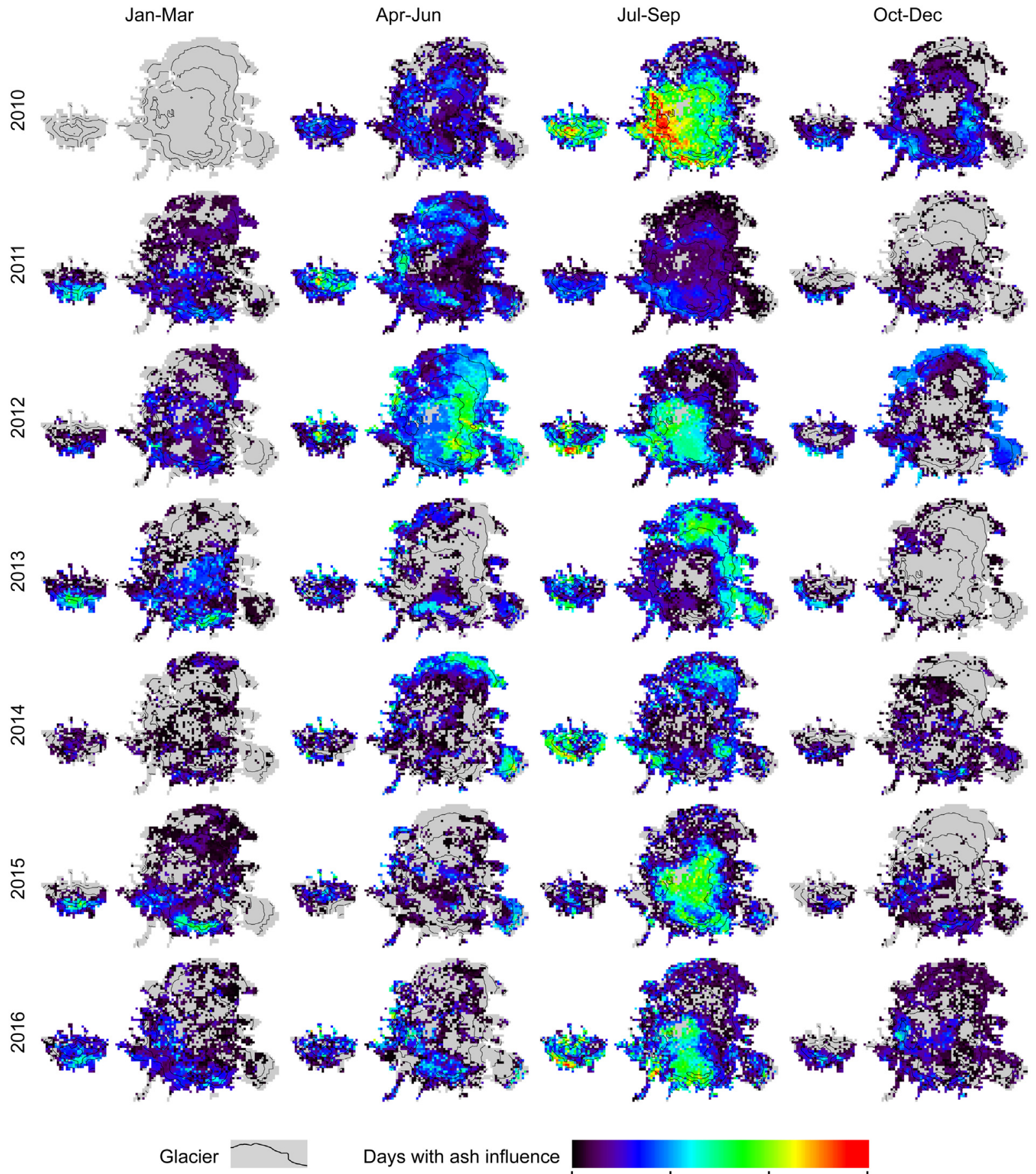

Days with ash influence

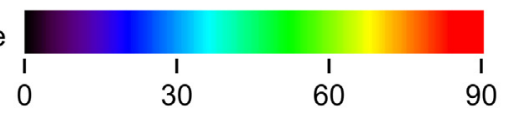

Fig. 6. Spatial distributions of seasonally cumulated ash-influenced areas on Eyjafjallajökull and Mýrdalsjökull ice caps over the post-eruption period $2010-2016$. The color code indicates the number of days per season for which a significant ( $95 \%$ level) albedo reduction was identified for the respective pixel.

amounts of ash deposition. Most prominent in this respect is the persistent ash influence across the southern part of Eyjafjallajökull (Figs. 6 and 8), for which also aerial photography clearly provides visible evidence (Fig. 9). This location is clearly related to the highest volumes of ashfall (Fig. 1a). On 17 April 2010, ash fallout towards the south of the summit caldera produced on-glacier depositions of $>0.5 \mathrm{~m}$ thickness (Gudmundsson et al., 2012). These are the thickest observed in the context of this eruption. Also, the areas of most persistent albedo reduction which are observed along the western (Goðabunga) and southern (Háabunga) rim of the summit plateau of Mýrdalsjökull (Figs. 6 and 8) coincide with areas of high ash deposition
(Gudmundsson et al., 2012). Continuous and uninterrupted ash influences of at least one-month duration are largely limited to these areas (Fig. 8) while short-term ash influences on glacier albedo in the order of days or weeks are found repeatedly across large parts of the ice cap. The fact that across Goðabunga and Háabunga on Mýrdalsjökull ash-influenced areas are identified not only during the summer months but during all seasons of the year (Fig. 6) can be explained by terrain effects. These local summits show convex relief features which are more directly exposed to wind as neighboring concave features. This leads to much lower snow depths on the convex parts and to the repeated exposure of underlying ash deposits. 

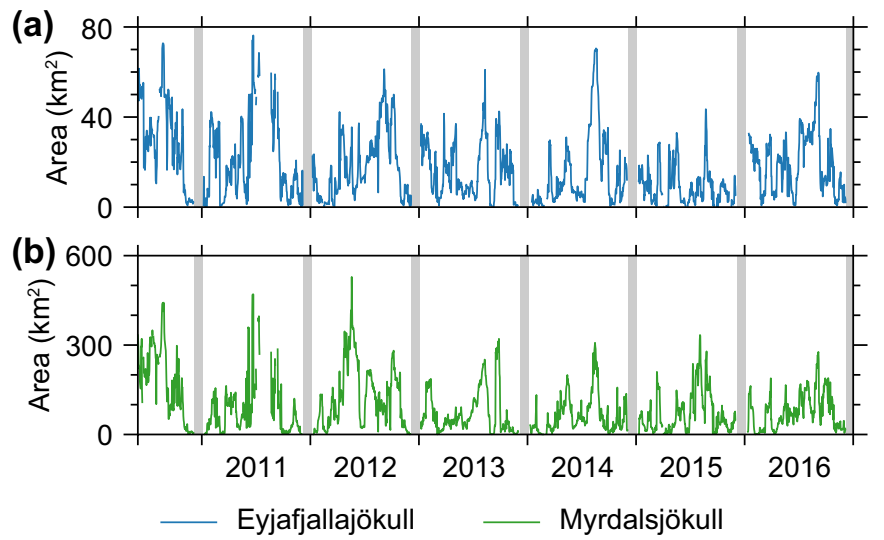

Fig. 7. Daily extents of the significantly ash-influenced areas on Eyjafjallajökull (a) and Mýrdalsjökull (b) ice caps over the post-eruption period 2010-2016. Periods where no data are available due to seasonal darkness are marked in grey.

Influence of ashfall is also observed across the reference areas on Vatnajökull even if those lie beyond the outer isopach $\left(0.1 * 10^{-3} \mathrm{~m}\right)$ drawn by Gudmundsson et al. (2012) to spatially delimit the main ash dispersal of the eruption. Especially the reference areas S, SW and W show a sustained disturbance of albedo conditions over the summer season 2010 (Fig. 2b). The drop of area-averaged albedo of $\sim 0.28$ across the reference areas over the period of the eruption (Fig. 4) indicates that even very small amounts of ash deposition lead to albedo reductions. This fact is in line with findings made for even thinner accumulations of atmospheric black carbon, which were found to substantially reduce Himalayan glacier albedo despite the overall extremely little mass of the deposited material (e.g. He et al., 2018; Ming et al., 2012). It can be also related to a clumping mechanism of finer particles on ice or snow surfaces as observed in Iceland after the snowdust storm described by Dagsson-Waldhauserova et al. (2015). Such a clumping mechanism of fine silty dust can reduce the snow albedo to a greater degree than a deposition of black volcanic sand or black carbon (Meinander et al., 2014; Peltoniemi et al., 2015).

The return to higher than before summer albedos on Vatnajökull in 2015 and 2016 indicates recovery from the above mentioned influences. Ash deposition from an eruption of Grímsvötn volcano covered an area of $\sim 1280 \mathrm{~km}^{2}$ on northwestern Vatnajökull in early November 2004 (Jude-Eton et al., 2012) and slightly influenced the albedo in this area over a four-years period (Möller et al., 2014). Hence, the mean intra-annual albedo cycle of the pre-eruption period (2000-2009, Fig. 4) partly incorporates a temporally limited darkening of the glacier following this earlier eruption. A distinct peak in albedo reduction on
Vatnajökull during summer 2011 (Fig. 4) gives evidence for the eruption of Grímsvötn in May 2011. The effects of this eruption are clearly visible across all eight reference areas (Fig. 2b). Reference areas with disturbed albedo conditions increase in number over June 2011. Subsequently, a 43-days period follows during which disturbed albedo conditions are identified all across Vatnajökull (Fig. 2c). The most direct ash dispersal of this eruption was largely directed towards the south (e.g. Tesche et al., 2012), spreading across the area already masked out from Vatnajökull (cf. Fig. 1b). However, the observed lower than usual summer albedos in 2011 and 2012 (Fig. 4) suggest that marginal influences beyond the main ash dispersal region as they were identified for the Eyjafjalljökull 2010 eruption (Figs. 2 and 4) also exist here. Assuming a similar four-year period for removal of these influences as for the eruption of Grímsvötn in 2004 (Möller et al., 2014) would leave the years 2015 and 2016 without any darkening influences.

Both temporal and spatial patterns of significant, ash-influenced albedo reductions suggest a relation to intra-annual climate variability. Albedo reductions tend to disappear or at least diminish over the winter seasons and are most pronounced during summer (Fig. 4). In the course of the ablation season, the newly accumulated snow is removed in areas lying below the transient snowline and previously buried ash layers get exposed once again. Above the equilibrium line it is impossible that the ash layers of the Eyjafjallajökull eruption get re-exposed over extensive areas, as winter accumulation on top of Mýrdalsjökull reaches up to $\sim 12.0 \mathrm{~m}$ (Ágústsson et al., 2013). However, terrain features that stick out of the smooth glacier surface are typically characterized by much thinner annual snow layers as the neighboring areas. These protrusions are often the result of obstacles in the bedrock that are traced to the glacier surface by a reduction of local ice flow. At such locations, ash layers get re-exposed even in the accumulation areas (Fig. 9c). Once the ash dries, wind erosion occurs and the ash is dispersed across the surrounding glacier areas, leading to a widespread reduction in albedo even above the equilibrium line.

The significant albedo reductions across the central plateau of Mýrdalsjökull in 2012, 2015 and 2016 (Fig. 6) must nevertheless be ascribed to external forcing. The vast extent of the affected areas rebuts a formation by wind-drifted ash from locally exposed deposits at isolated protrusions. This external forcing is likely resulting from dust storm events, which frequently occur on the sandur plain Skeiðarársandur between Mýrdalsjökull and Vatnajökull (Arnalds et al., 2013, 2016; Dagsson-Waldhauserova et al., 2014; Wittmann et al., 2017). Lemarquis (2018) documented and measured several dust events in Fljotshlid, west of Eyjafjallajökull, with origin from the Mýrdalsandur dust source in 2018. This shows that particular weather patterns transport dust over both ice caps, Eyjafjallajökull and Mýrdalsjökull, with very likely deposition on them and albedo reduction as observed
All ash influence

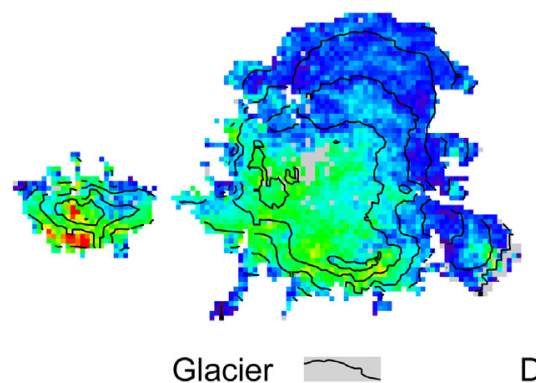

Ash influence $\geq 1$ week

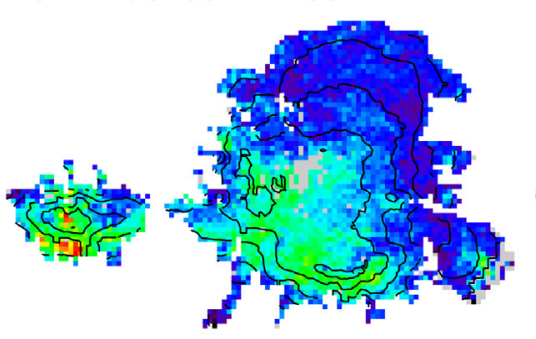

Ash influence $\geq 1$ month

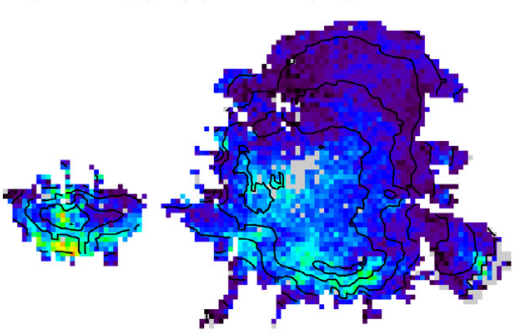

Days with ash influence

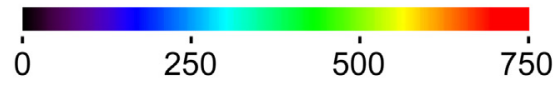

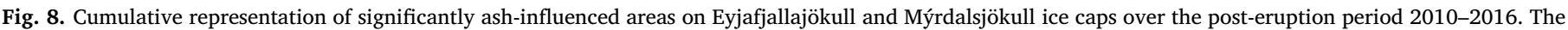

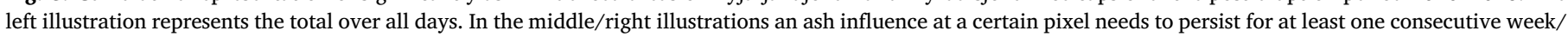

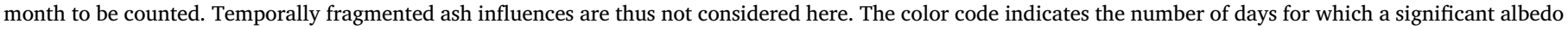
reduction was identified for the respective pixel. 


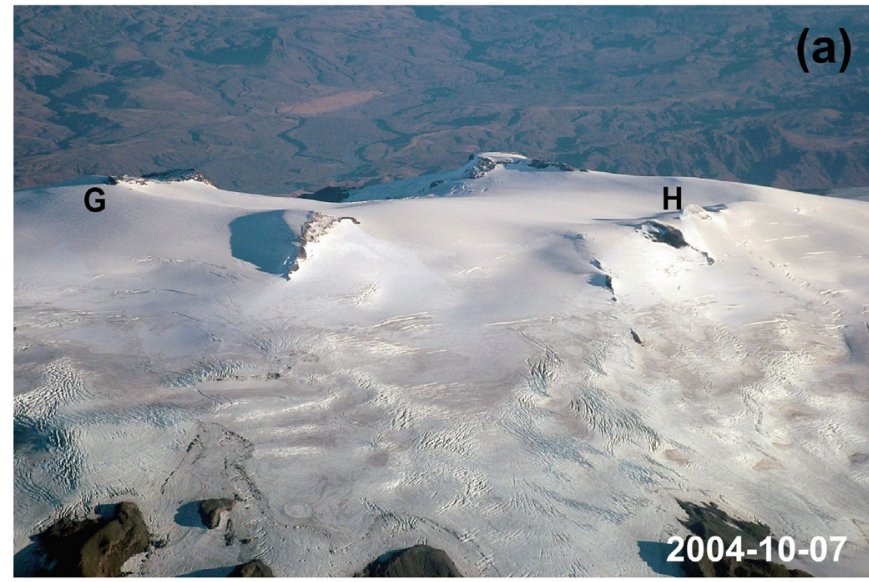

(b)
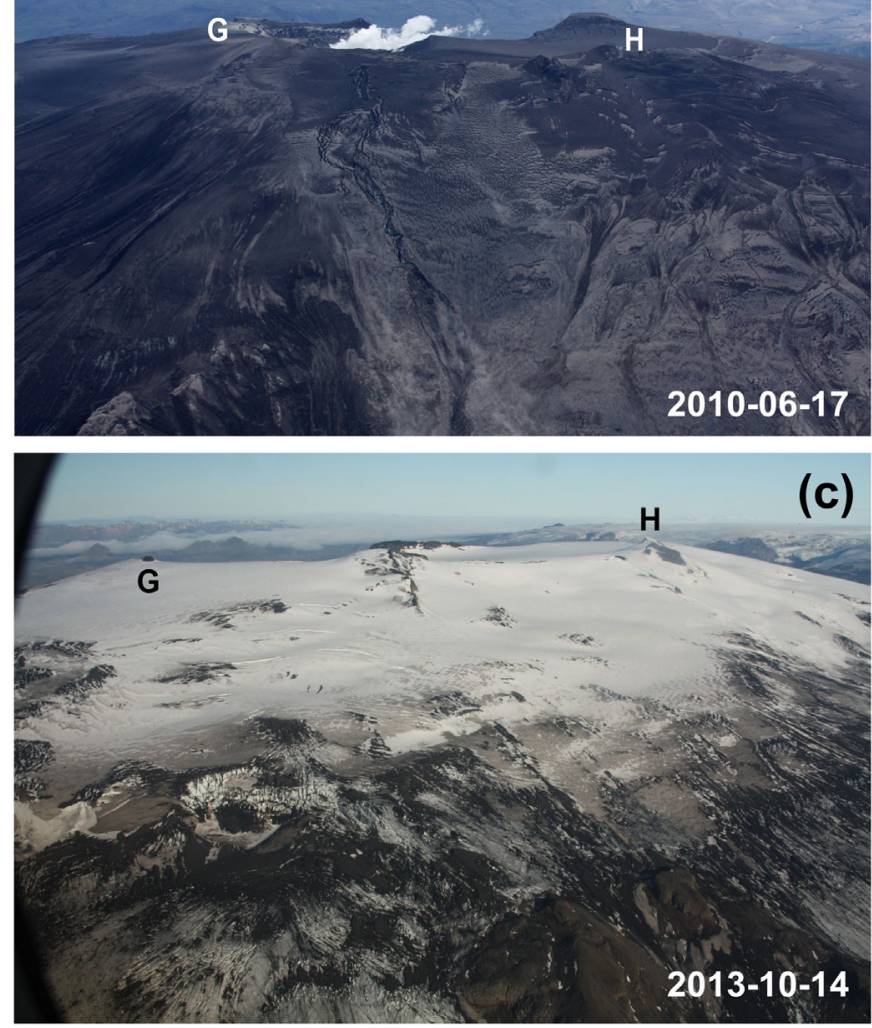

Fig. 9. Aerial views of Eyjafjallajökull from the south (dates in lower right hand corner), showing the ice cap ahead of the eruption (a), right after the eruption in 2010 (b) and three years later (c). The nunataks of Goðasteinn (G) and Hámundur $(\mathrm{H})$ are indicated on all photos.

by Wittmann et al. (2017). In this respect the term 'external forcing' has, however, to be used with care. Considerable ash deposition from the original fallout also occurred across the sandur plains described above (Fig. 1a). This fueled the dust sources in these areas as the fine grained ashes are easily transported by wind. Hence, ash dispersal from the Eyjafjalljökull 2010 eruption also increased the efficiency of any dust storms with respect to resulting glacier albedo reductions. The 'external forcing' is thus also linked to the original fallout.

To support the assumption of an external forcing of the extensive albedo reductions on the central plateau of Mýrdalsjökull we exemplarily show the relation of two peaks in the extent of significantly ash-influenced areas on Mýrdalsjökull to documented major dust storm events. The all time-high extent in the period 17-27 May 2012 (Fig. 7b), which was associated with significant, ash-influenced albedo reductions across vast parts of the central plateau of the ice cap (Fig. 6) and an extraordinary reduction of ice cap-wide mean albedo (Fig. 4), coincides with the occurrence of a strong dust storm on 21 May 2012 (Dragosics et al., 2015). In addition, SYNOP codes from the weather stations in South Iceland reported dust observation for the whole period of 13-19 May 2012. Another strong albedo reduction which occurred in September 2012 (Fig. 7b) can probably be related to a dust storm event which occurred on 18 September 2012 across the sandur plain in between Mýrdalsjökull and Vatnajökull (Groot Zwaaftink et al., 2017). SYNOP codes reported dust observation in the period 8-11 September 2012 as well as most of them were captured by MODIS. The influence of high dust activity in South Iceland in 2012 is likely the cause of these specific albedo reductions.

Overall, the significant albedo reductions during 2010-2016 suggest a complex combination of forcings, i.e. influences of initially deposited volcanic ash and of the annual cycle of snowfall and snow cover. However, redistribution of ash or local dust materials by strong storm events may lead to albedo reductions which are detected by the algorithm as well. Such dust storms occur most frequently in South Iceland in vicinity of the glaciers (Butwin et al., 2018; Dagsson-Waldhauserova et al., 2016; Lemarquis, 2018; Nakashima and Dagsson-Waldhauserova, 2018), but they are also known to episodically influence the northern parts of Vatnajökull (Wittmann et al., 2017). Therefore, it cannot be ruled out that indirect influences affect the results via alterations of the albedo across the reference areas, even if we excluded reference areas with obviously disturbed albedo conditions from the analysis. The spatial coincidence of significantly ash-influenced areas identified in this study and the areas with high amounts of initial ashfall is thus an important criterion. It provides some evidence if the areas with significantly reduced albedo identified with the method applied show a relation to the initially deposited ash of the Eyjafjallajökull eruption or need to be ascribed to dust storm-related secondary deposits.

Last but not least, model uncertainties in terms of the accuracy of the threshold criteria may impact the extent of areas with significantly reduced albedo. The rather arbitrary choice of the \pm 0.02 range during generation of the hypothetic albedo fields $\widehat{\gamma}_{X, m}$ (cf. Section 4), in contrast, has no implications for the results presented. In Möller et al. (2014), where our method was introduced, a range of \pm 0.05 was applied. Such a large range is not necessary here because of a far more extensive lookup table, which results from a longer pre-eruption period. We tested ranges of $\pm 0.03, \pm 0.02$ and \pm 0.01 in the run-up to this study, but found that the final results hardly differ at all. Noticeable differences only appeared in the standard deviations of the hypothetic albedo fields $\hat{\gamma}_{X, m}$, which obviously increased with the size of the chosen range. These standard deviations are, however, only important for the application of the Student's $t$-test at the end of the methodical workflow. At this stage, the potentially ash-related albedo reductions already exceed the thresholds of natural variability and virtually all of them are large enough to pass the significance test no matter if slightly smaller or larger standard deviations are applied.

\section{Conclusion}

MODIS data-based geostatistical analysis revealed significant albedo reductions across Eyjafjallajökull and Mýrdalsjökull ice caps following the April-May 2010 explosive eruption of Eyjafjallajökull volcano. The annual cycles of area-averaged albedo of the two ice caps during 2010-2012 show substantial deviations from the pre-eruption mean (2001-2009). These deviations peak especially in summer. In 2010, they started right after the end of the explosive eruption in late May. Area-averaged albedos on Eyjafjallajökull and Mýrdalsjökull ice caps drop from 0.68 to 0.11 and from 0.73 to 0.14 , respectively, over the eruption period. Even on the only marginally impacted eastern parts of Vatnajökull a drop of area-averaged albedo from 0.77 to 0.49 is 
evident.

Over the post eruption period (2010-2016) on average we found significant albedo reductions for $15.4 \%$ of the area of Eyjafjallajökull and $10.9 \%$ of the area of Mýrdalsjökull. The areas concentrate mainly on the southern part of Eyjafjallajökull and the southwestern and southern parts of Mýrdalsjökull, showing a spatial coincidence with the regions of highest ash deposition during the eruption. The area-averaged albedo across these areas is reduced by $0.19 \pm 0.11$ and $0.17 \pm 0.10$, respectively. Extents of areas with significant albedo reductions on Eyjafjallajökull and Mýrdalsjökull decrease over time. The magnitude of albedo reduction within these areas decreases with time on both ice caps, but rates are distinctly smaller on Mýrdalsjökull.

Only parts of the identified areas with significant albedo reductions can be attributed to the direct influence of ashes deposited by fallout from the Eyjafjallajökull 2010 eruption. Such a persistent direct ash influence on the albedo over the entire post-eruption period (2010-2016) can only be verified for the direct southerly vicinity of the eruption vent on Eyjafjallajökull itself and for the western and southern rim of the central plateau of Mýrdalsjökull. The widespread albedo reductions which were identified across this central plateau during years after the first winter season cannot directly result from re-emerging ash deposits because of extremely high annual accumulation sums in this area. Instead, they presumably result from a) ashes cropping out at isolated protrusions of the ice cap that are redistributed by wind drift and b) secondary ash remobilization or dust deposition originating in local dust sources which lie in direct vicinity to the ice caps. The latter effect is exemplified by severe dust storms in 2012 .

We conclude that the persistent albedo reduction on Eyjafjallajökull over 2010-2016 is entirely due to the high amounts of initial ash deposition (up to $>0.5 \mathrm{~m}$ ). Across all areas on directly neighboring Mýrdalsjökull, where the initial deposition was more than one order of magnitude smaller, the ash cover-related albedo reduction shows a distinct decline over time.

\section{Acknowledgements}

This study was financed by grants no. SCHN680/6-1 and KU1476/51 of the German Research Foundation (DFG). ASTER GDEM is a product of METI and NASA. Helpful comments by Helgi Björnsson on an earlier version of the manuscript are gratefully acknowledged.

\section{References}

Adhikary, S., Nakawo, M., Seko, K., Shakya, B., 2000. Dust influence on the melting process of glacier ice: experimental results from Lirung glacier, Nepal Himalayas. In: IAHS Redbooks. vol. 264. pp. 43-52.

Ágústsson, H., Hannesdóttir, H., Thorsteinsson, T., Pálsson, F., Oddsson, B., Ólafsson, H., 2013. Mass balance of Mýrdalsjökull ice cap and comparison with observed and simulated precipitation. In: Geophysical Research Abstracts. vol. 15 (EGU201313302).

Arnalds, O., Thorarinsdottir, E.F., Thorsson, J., Waldhauserova, P.D., Agustdottir, A.M. 2013. An extreme wind erosion event of the fresh Eyjafjallajökull 2010 volcanic ash. Sci. Rep. 3, 1257. https://doi.org/10.1038/srep01257.

Arnalds, O., Dagsson-Waldhauserova, P., Olafsson, H., 2016. The Icelandic volcanic aeolian environment: processes and impacts - a review. Aeolian Res. 20, 176-195.

Björnsson, H., 2017. The Glaciers of Iceland - a Historical, Cultural and Scientific Overview. Springer (613 pp.).

Björnsson, H., Pálsson, F., 2008. Icelandic glaciers. Jökull 58, 365-386.

Björnsson, H., Pálsson, F., Gudmundsson, S., Magnússon, E., Adalgeirsdóttir, G., Jóhannesson, T., Berthier, E., Sigurdsson, O., Thorsteinsson, T., 2013. Contribution of Icelandic ice caps to sea level rise: trends and variability since the Little Ice Age. Geophys. Res. Lett. 40, 1546-1550. https://doi.org/10.1002/grl.50278.

Borisova, A.Y., Toutain, J.-P., Stefansson, A., Gouy, S., and de Parseval, P., 2012. Processes controlling the 2010 Eyjafjallajökull explosive eruption. J. Geophys. Res. 117, B05202, doi:https://doi.org/10.1029/2012JB009213.

Butwin, M.K., von Löwis, S., Pfeffer, M., Thorsteinsson, Th., 2018. The effects of volcanic eruptions on the frequency of particulate matter suspension events in Iceland. J. Aerosol Sci. https://doi.org/10.1016/j.jaerosci.2018.12.004. in press.

Crochet, P., Jóhannesson, T., Jónsson, T., Sigurðsson, O., Björnsson, H., Pálsson, F., Barstad, I., 2007. Estimating the spatial distribution of precipitation in Iceland using a linear model of orographic precipitation. J. Hydrometeorol. 8, 1285-1306.

Dagsson-Waldhauserova, P., Arnalds, O., Ólafsson, H., 2014. Long-term variability of dust events in Iceland (1949-2011). Atmos. Chem. Phys. 14, 13411-13422. https://doi. org/10.5194/acp-14-13411-2014.

Dagsson-Waldhauserova, P., Arnalds, O., Ólafsson, H., Hladil, J., Skala, R., Navratil, T., Chadimova, L., Meinander, O., 2015. Snow-dust storm: unique case study from Iceland, March 6-7, 2013. Aeolian Res. 16, 69-74.

Dagsson-Waldhauserova, P., Magnusdottir, A.Ö., Olafsson, H., Arnalds, O., 2016. The Spatial Variation of Dust Particulate Matter Concentrations during Two Icelandic Dust Storms in 2015. Atmosphere 7, 77. https://doi.org/10.3390/atmos7060077.

Dragosics, M., Thorsteinsson, T., Pálsson, F., 2015. Albedo changes on Vatnajökull associated with dust events on Iceland. Geophys. Res. Abstr. 17 (EGU2015-10355-11).

Dragosics, M., Meinander, O., Jónsdóttir, T., Dürig, T., De Leeuw, G., Pálsson, F., DagssonWaldhauserová, P., Thorsteinsson, T., 2016. Insulation effects of Icelandic dust and volcanic ash on snow and ice. Arab. J. Geosci. 9, 126. https://doi.org/10.1007/ s12517-015-2224-6.

Gascoin, S., Guðmundsson, S., Aðalgeirsdóttir, G., Pálsson, F., Schmidt, L., Berthier, E., Björnsson, H., 2017. Evaluation of MODIS albedo product over ice caps in Iceland and impact of volcanic eruptions on their albedo. Remote Sens. 9, 399. https://doi.org/ $10.3390 /$ rs9050399.

Groot Zwaaftink, C.D., Arnalds, O., Dagsson-Waldhauserova, P., Eckhardt, S., Prospero, J.M., Stohl, A., 2017. Temporal and spatial variability of Icelandic dust emission and atmospheric transport. Atmos. Chem. Phys. 17, 10865-10878.

Gudmundsson, M.T., Pedersen, R., Vogfjörd, K., Thorbjarnardóttir, B., Jakobsdóttir, S., Matthew, J.R., 2011. Eruptions of Eyjafjallajökull volcano, Iceland. EOS 91, 190-191. https://doi.org/10.1029/2010EO210002.

Gudmundsson, M.T., et al., 2012. Ash generation and distribution from the April-May 2010 eruption of Eyjafjallajökull, Iceland. Sci. Rep. 2, 572. https://doi.org/10.1038/ srep00572.

Hall, D.K., Riggs, G.A., Salomonson, V.V., DiGirolamo, N.E., Bayr, K.J., 2002. MODIS snow-cover products. Remote Sens. Environ. 83, 181-194.

He, C., Flanner, M.G., Chen, F., Barlage, M., Liou, K.-N., Kang, S., Ming, J., Qian, Y., 2018 Black carbon-induced snow albedo reduction over the Tibetan Plateau: uncertainties from snow grain shape and aerosol-snow mixing state based on an updated SNICAR model. Atmos. Chem. Phys. 18, 11507-11527.

Jakobsson, S.P., Jónasson, K., Sigurdsson, I.A., 2008. The three igneous rock series of Iceland. Jökull 58, 117-138.

Jude-Eton, T.C., Thordarson, T., Gudmundsson, M.T., Oddsson, B., 2012. Dynamics, stratigraphy and proximal dispersal of supraglacial tephra during the ice-confined 2004 eruption at Grímsvötn volcano, Iceland. Bull. Volcanol. 74, 1057-1082.

Kohavi, R., 1995. A study of cross-validation and bootstrap for accuracy estimation and model selection. In: Mellish, C. (Ed.), Proceedings of the 14th International Joint Conference on Artificial Intelligence. Morgan Kaufmann, San Francisco, pp. 1137-1143.

Larsen, G., Gudmundsson, M.T., Björnsson, H., 1998. Eight centuries of periodic volcanism at the centre of the Iceland hotspot revealed by glacier tephrostratigraphy. Geology 26, 943-946.

Lemarquis, L.M., 2018. Frequency and Origin of Dust Events in Fljótshlíð, South Iceland, in 2017. B.Sc. thesis. Faculty of Earth Sciences, University of Iceland (25 pp.).

Meinander, O., Kontu, A., Virkkula, A., Arola, A., Backman, L., Dagsson-Waldhauserová, P., Järvinen, O., Manninen, T., Svensson, J., de Leeuw, G., Leppäranta, M., 2014. Brief communication: light-absorbing impurities can reduce the density of melting snow. Cryosphere 8, 991-995.

Ming, J., Du, Z., Xiao, C., Xu, X., Zhang, D., 2012. Darkening of the mid-Himalayan glaciers since 2000 and the potential causes. Environ. Res. Lett. 7, 014021. https:// doi.org/10.1088/1748-9326/7/1/014021.

Möller, M., 2012. A minimal, statistical model for the surface albedo of Vestfonna ice cap, Svalbard. Cryosphere 6, 1049-1061.

Möller, M., Möller, R., 2017. Modeling glacier-surface albedo across Svalbard for the 1979-2015 period: the HiRSvaC500- $\alpha$ data set. J. Adv. Model. Earth Syst. 9, 404-422. https://doi.org/10.1002/2016MS000752.

Möller, R., Möller, M., Björnsson, H., Gudmundsson, S., Pálsson, F., Oddsson, B., Kukla, P.A., Schneider, C., 2014. MODIS-derived albedo changes of Vatnajökull (Iceland) due to tephra deposition from the 2004 Grimsvötn eruption. Int. J. Appl. Earth Obs. Geoinf. 26, 256-269. https://doi.org/10.1016/j.jag.2013.08.005.

Möller, R., Möller, M., Kukla, P.A., Schneider, C., 2016. Impact of supraglacial deposits of tephra from Grímsvötn volcano, Iceland, on glacier ablation. J. Glaciol. 62 (235), 933-943. https://doi.org/10.1017/jog.2016.82.

Möller, R., Möller, M., Kukla, P.A., Schneider, C., 2018. Modulation of glacier ablation by tephra coverage from Eyjafjallajökull and Grímsvötn volcanoes, Iceland: an automated field experiment. Earth Syst. Sci. Data 10, 53-60. https://doi.org/10.5194/ essd-10-53-2018.

Nakashima, M., Dagsson-Waldhauserova, P., 2018. Variables influencing aerosol dust activity: a 60 year analysis of ten Icelandic weather stations from 1950-2009. Front. Earth Sci. 6 (accepted).

Nield, J.M., Chiverrell, R.C., Darby, S.E., Leyland, J., Vircavs, L.H., Jacobs, B., 2013. Complex spatial feedbacks of tephra redistribution, ice melt and surface roughness modulate ablation on tephra covered glaciers. Earth Surf. Process. Landf. 38, 95-102. https://doi.org/10.1002/esp.3352.

Peltoniemi, J.I., Gritsevich, M., Hakala, T., Dagsson-Waldhauserová, P., Arnalds, Ó., Anttila, K., Hannula, H.-R., Kivekäs, N., Lihavainen, H., Meinander, O., Svensson, J., Virkkula, A., de Leeuw, G., 2015. Soot on snow experiment: bidirectional reflectance factor measurements of contaminated snow. Cryosphere 9, 3075-3111.

Pfeer, W.T., Arendt, A.A., Bliss, A., Bolch, T., Cogley, J.G., Gardner, A.S., Hagen, J.-O., Hock, R., Kaser, G., Kienholz, C., Miles, E.S., Moholdt, G., Molg, N., Paul, F., Radic, V., Rastner, P., Raup, B.H., Rich, J., Sharp, M.J., Andreassen, L.M., Bajracharya, S., Barrand, N.E., Beedle, M.J., Berthier, E., Bhambri, R., Brown, I., Burgess, D.O., Burgess, E.W., Cawkwell, F., Chinn, T., Copland, L., Cullen, N.J., Davies, B., Angelis, 
H.D., Fountain, A.G., Frey, H., Gien, B.A., Glasser, N.F., Gurney, S.D., Hagg, W., Hall, D.K., Haritashya, U.K., Hartmann, G., Herreid, S., Howat, I., Jiskoot, H., Khromova, T.E., Klein, A., Kohler, J., Konig, M., Kriegel, D., Kutuzov, S., Lavrentiev, I., Le Bris, R., Li, X., Manley, W.F., Mayer, C., Menounos, B., Mercer, A., Mool, P., Negrete, A., Nosenko, G., Nuth, C., Osmonov, A., Pettersson, R., Racoviteanu, A., Ranzi, R., Sarkaya, M.A., Schneider, C., Sigursson, O., Sirguey, P., Stokes, C.R., Wheate, R., Wolken, G.J., Wu, L.Z., Wyatt, F.R., 2014. The Randolph Glacier Inventory : a globally complete inventory of glaciers. J. Glaciol. 60 (221), 537-552.

Racoviteanu, A.E., Williams, M.W., Barry, R.G., 2008. Optical remote sensing of glacie characteristics: a review with focus on the Himalaya. Sensors 8, 3355-3383. https:// doi.org/10.3390/s8053355.

Schaaf, C.B., et al., 2002. First operational BRDF, albedo and nadir reflectance products from MODIS. Remote Sens. Environ. 83, 135-148.

Stevenson, J.A., et al., 2012. Distal deposition of tephra from the Eyjafjallajökull 2010 summit eruption. J. Geophys. Res. 117, B00C10. https://doi.org/10.1029/ 2011JB008904.

Stroeve, J., Box, J.E., Gao, F., Liang, S., Nolin, A., Schaaf, C., 2005. Accuracy assessment of the MODIS 16-day albedo product for snow: comparison with Greenland in situ measurements. Remote Sens. Environ. 94, 46-60.

Tachikawa, T., Hato, M., Kaku, M., Iwasaki, A., 2011. The Characteristics of ASTER GDEM Version 2. IGARSS.

Tesche, M., Glantz, P., Johansson, C., Norman, M., Hiebsch, A., Ansmann, A., Althausen, D., Engelmann, R., Seifert, P., 2012. Volcanic ash over Scandinavia originating from the Grímsvötn eruptions in May 2011. J. Geophys. Res. 117, D09201. https://doi. org/10.1029/2011JD017090.

Thordarson, T., Larsen, G., 2007. Volcanism in Iceland in historical times: volcano types, eruption styles and eruptive history. J. Geodyn. 43, 118-152.

Toller, G., Xiong, X., Sun, J., Wenny, B.N., Geng, X., Kuyper, J., Angal, A., Chen, H., Madhavan, S., Wu, A., 2013. Terra and Aqua moderate-resolution imaging spectroradiometer collection 6 level 1B algorithm. J. Appl. Remote. Sens. 7, 073557. https:// doi.org/10.1117/1.JRS.7.073557.

Wittmann, M., Groot Zwaaftink, C.D., Steffensen Schmidt, L., Guðmundsson, S., Pálsson, F., Arnalds, O., Björnsson, H., Thorsteinsson, T., Stohl, A., 2017. Impact of dust deposition on the albedo of Vatnajökull ice cap, Iceland. Cryosphere 11, 741-754. 